\title{
Development of frozen food Royal Food UMKM
}

\author{
Onan M Siregar ${ }^{1 *}$, Selwendri ${ }^{1}$ \\ ${ }^{1}$ Department of Business Administration Faculty of Economics and Business, Universitas \\ Sumatera Utara, Medan, Indonesia \\ *Email: onan@usu.ac.id
}

\begin{abstract}
Community service activities aim at increasing the competitiveness of fostered partners in dealing with market developments. The potential of developing frozen food UMKM products is still very open because it is very popular among many people in the City of Medan. Royal Food also experiences the same thing as most UKMKs in Medan, which generally have limited human resource quality of education. The workforce in UKMK is dominated by workers with low education and do not have good financial management and the low utilization of technology. This community service activity was carried out over a period of six months. Activities carried out in the form of socialization and counseling to partners, training in business development and marketing, safe and hygienic production practices and designing more attractive packaging, carrying out production and marketing to partner monitoring and evaluation. After getting a touch of good design, proper management, modernization of production equipment, attractive promotional media, UMKM Royal Food is able to experience business development with increasingly high sales and more competitive products.
\end{abstract}

\section{Keywords : Business development, Frozen food MSMEs, Royal Food MSMEs}

\begin{abstract}
Abstrak
Kegiatan pengabdian pada masyarakat ini bertujuan meningkatkan daya saing mitra binaan dalam menghadapi perkembangan pasar. Potensi pengembangan produk UMKM makanan beku ini masih sangat terbuka karena sangat disukai oleh banyak kalangan di Kota Medan. Royal Food juga mengalami hal yang sama dengan kebanyakan UKMK yang ada di Kota Medan yaitu pada umumnya memiliki kualitas sumber daya manusia yang terbatas tingkat pendidikannya. Tenaga kerja di UKMK didominasi oleh tenaga kerja yang berpendidikan rendah dan belum memiliki manajemen keuangan yang baik serta masih rendahnya pemanfaatan teknologi. Kegiatan pengabdian masyarakat ini dilaksanakan selama kurun waktu enam bulan. Kegiatan yang dilaksanakan berupa sosialisasi dan penyuluhan kepada mitra, pelatihan pengembangan usaha dan pemasaran, praktik produksi yang aman dan higienis serta mendisain kemasan yang lebih menarik, melaksanakan produksi dan pemasaran sampai kepada monitoring dan evaluasi mitra. Setelah mendapatkan sentuhan desain yang baik, manajemen yang tepat, modernisasi alat produksi, media promosi yang menarik UMKM Royal Food mampu mengalami pengembangan usaha dengan semakin tingginya penjualan dan produk yang dijual semakin kompetitif.
\end{abstract}

Kata Kunci: Pengembangan bisnis, UMKM makanan beku, UMKM Royal Food

\section{PENDAHULUAN (INTRODUCTION)}

Sektor Usaha Mikro Kecil dan Menengah (UMKM) mempunyai peluang pasar yang sangat besar karena selalu ada pasar bagi produksi barang dan jasa mereka mengingat sektor Usaha Mikro Kecil dan Menengah (UMKM) merupakan penghasil barang dan jasa khususnya bagi masyarakat golongan menengah kebawah dengan daya beli yang rendah. Selain itu Usaha Usaha Mikro Kecil dan Menengah (UMKM) mampu bertahan di saat krisis disebabkan modal usahanya dan modal sendiri (Bagus Ardiyanto, 2013).

Usaha kecil, Menengah dan Koperasi (UKMK) merupakan kelompok usaha ekonomi yang penting dalam perekonomian Kota Medan. Hal ini disebabkan, usaha kecil menengah dan koperasi 
merupakan sektor usaha yang memiliki jumlah terbesar dengan daya serap angkatan kerja yang signifikan. Oleh karena kesenjangan pendapatan yang cukup besar masih terjadi antara pengusaha besar dengan usaha kecil, menengah dan koperasi (UKMK), pengembangan daya saing UKMK, secara langsung merupakan upaya dalam rangka peningkatan kesejahteraan rakyat banyak, sekaligus mempersempit kesenjangan ekonomi.

Royal Food salah satu UKMK yang berdiri di Kota Medan pada tahun 2016 sebagai industri rumahan (home Industry) yang didirikan oleh Said Muhammad Dauly yang bergerak dalam bidang usaha makanan beku yang menghasilkan berbagai produk antara lain dimsum, pancake, dan kebab. Usaha yang baru berdiri dalam 3 (tiga) tahun tersebut sudah memberikan profit yang lumayan yaitu dengan omset 50 juta sampai 80 juta dalam sebulan dengan harga Rp 35 ribu sampai dengan Rp. 70 ribu per porsi. Hal ini karena saat ini makanan beku terutama dimsum sangat digemari oleh para kaum muda dan menjadi trend bagi generasi milenial. Selain itu sistem pemasaran yang dilakukan secara online dengan menggunakan berbagai media sosial seperti facebook dan instragram membuat usaha ini semakin cepat berkembang dan menghasilkan keuntungan yang sangat baik.

Akan tetapi dalam menjalankan usahanya produksi makanan beku yang dihasilkan masih dilakukan secara manual. Begitu juga dengan sistem manajemen usaha dari Royal Food masih sangat sederhana

Royal Food juga mengalami hal yang sama dengan kebanyakan UKMK yang ada di Kota Medan yaitu pada umumnya memiliki kualitas sumber daya manusia yang terbatas tingkat keahliannya dan pendidikannya. Tenaga kerja di UKMK didominasi oleh tenaga kerja yang berpendidikan rendah dan belum memiliki manajemen keuangan yang baik serta masih rendahnya pemanfaatan teknologi.

Royal Food masih dominan menggunakan peralatan manual, yang membuat tidak menghasilkan produksi dalam jumlah besar. Oleh karena itu tim pengabdi merasa Royal Food sebagai mitra dari pengabdian dapat dikembangkan untuk menjadi lebih baik dari saat ini dalam hal pengelolaan manajemen, pemasaran, produksi, pengelolaan sumber daya manusia.

Dari paparan tersebut di atas, maka dapat dipetakan permasalahan Mitra UMKM Makanan Beku Royal Food berdasarkan prioritas kebutuhan mitra dengan meningkatkan kapasitas produksi masih terbatas, baik secara kuantitas maupun kualitas, menerapkan penggunaan alat bantu produksi yang tepat untuk meningkatkan produktivitas, membekali kemampuan manajemen produksi, keuangan, dan pemasaran agar tertata dengan baik, meningkatkan metode pemasaran tidak hanya menggunakan media sosial saja tetapi dengan cara yang konvesional sehingga memperlebar segmentasi kosumen tidak hanya terbatas kepada konsumen yang menggunakan teknologi dalam pemesanan.

\section{METODE PELAKSANAAN}

Kegiatan pengabdian masyarakat ini menggunakan metode

1. Ceramah untuk menyampaikan pengetahuan secara umum tentang pengembangan usaha kecil untuk menghadapi persaingan dengan memperbaiki manajemen dengan melakukan pelatihan Pelatihan bertujuan untuk memberikan motivasi kepada mitra agar memiliki semangat berwirausaha dan memiliki ketrampilan untuk menjalankan usaha dengan lebih baik melalui memberikan masukan dan saran perbaikan terhadap manajemen usaha makanan beku. Pelatihan dilakukan di lokasi pengabdian kepada karyawan yang bekerja di bagian produksi dan administrasi dan penjualan.

2. Pemberian alat-alat/mesin untuk menghasilkan produk dalam jumlah yang lebih banyak dengan kualitas yang lebih baik dari sebelumnya serta memperbaiki desain kemasan

\section{HASIL DAN PEMBAHASAN}


Hasil dari pengabdian masyarakat pengembangan UMKM makanan beku royal food memfokuskan untuk meningkatkan omset penjualan dan memperbaiki kualitas produk yang dihasilkan dari kegiatan usaha yang dijalankan. Pada pelaksanaan pengabdian dilakukan dengan cara memperbaiki manajamen usaha yang dimulai dari produksi, pemasaran, SDM sampai ke keuangan. Selain itu mitra dibantu dengan memberikan peralatan yang mampu menunjang produksi dimsum dan makanan beku lainnya

Tim pengadian memberikan 2 (dua) alat yang diharapkan mampu memberikan dampak yang signifikan terhadap perbaikan produksi dan kualitas produk. Mesin yang diberikan adalah mesin pengadon serba guna dan mesin pencacah daging. Dengan menggunakan mesin-mesin tersebut akan memudahkan mitra untuk memproduksi bahan dasar pembuat makanan beku dengan efisien dan kualitas yang standar.

Tim pengabdian membuat prosedur pemilihan bahan-bahan pembuat makanan yang berkualitas.Dim sum yang siap saji, pastikan bahwa mutunya benar benar baik. Cari supplier dim sum yang bermutu. Jika mengambil dim sum dalam kondisi segar, pastikan dim sum tetap bagus. Jika membeli beku, pastikan saat menerimanya dalam kondisi beku dan bagus. Sementara jika dim sum dibuat tersendiri, pastikan bahwa bahan baku dan tepung pendukung yang digunakan untuk membuat dim sum adalah dari bahan bermutu bagus dan aman untuk dikonsumsi. Perhatikan cara pembuatannya benar benar standar sehingga rasanya lebih konsisten.

Tim pengabdian juga meminta kepada pemilik usaha untuk memperhatian masalah kebersihan dan sanitasi Kebersihan peralatan sangat menentukan rasa dim sum yang dihidangkan. Jika peralatan hidang, masak atau piranti lain yang kontak langsung dengan makanan dim sum kotor akan mempengaruhi mutu dari makanan. Dim sum mudah basi, atau kotoran yang tertinggal akan merusak penampilannya. Pembeli jadi risih jika tiba tiba ada sisa kotoran makanan yang bau atau lalat saat disajikan. Kebersihan karyawan perlu diperhatikan. Karyawan yang sehat dan penampilan baaik serta mengerti pentingnya sanitasi menentukan penerimaan makanan tersebut di konsumen. Karyawan yang sakit kulit misalnya membuat jijik pembeli. Pilih karyawan yang memiliki kepedulian pada kebersihan. Sanitasi dan kebersihan bahan baku dan tepung, akan menentukan hasil akhir dari dim sum yang dibuat.Jika bahan baku ayam misalnya dimasak dalam keadaan kotor dan banyak bulu maka pembeli juga merasa tidak nyaman. Maka ayam harus dicuci bersih dan dibersihkan bulunya agar dim sum yang disajikan tetap enak dan bagus.

Selain itu dilakukan pendampingan kepada mitra dengan memperbaiki lay out dan alur kerja agar pekerjaan yang dilakukan oleh pekerja lebih efisien dan tidak menimbulkan kelelahan kepada pekerja,membuat logo atau merek usaha yang sesuai dengan target market pemasaran yaitu kaum muda yang lebih dikenal dengan generasi milenial yang menjadi target market pemasaran UKMK Royal Food. Membuat logo sebagai usaha untuk melakukan branding terhadap usaha yang dijalankan, membuat packaging yang mencantumkan logo di semua produk untuk memperkuat citra merek produk.

\section{KESIMPULAN}

\subsection{Kesimpulan}

Kegiatan program pengabdian masyarakat ini diharapkan UMKM Royal Food mampu memberikan manfaat lebih pada pemilik usaha dan para pekerja dengan memberikan solusi beberapa permasalahan yang dihadapi. Selanjutnya mitra diharapkan mengelola usahanya dengan baik, mampu bersaing dan mengembangkan pasar lebih luas. Pada akhirnya mitra mendapatkan penghasilan yang lebih baik sehingga mampu menaikkan kesejahteraan pekerja

\subsection{Saran}


1. Mitra UMKM Royal Food harus memiliki kemampuan membuat inovasi produk dan memperbaiki manajemen yang meliputi operasional, pemasaran, keuangan, sumber daya manusia serta berusaha untuk memenuhi standar kualitas yang ditetapkan oleh BPOM.

2. Memperhatihan perubahan selera masyarakat, terutama kaum milenial yang menjadi konsumen utama dari produk makanan beku yang dijual.

\section{UCAPAN TERIMAKASIH}

Artikel ini merupakan salah satu hasil dari Program Pengabdian kepada Masyarakat yang Dibiayai oleh dana NON PNBP Universitas Sumatera Utara Sesuai dengan Surat Perjanjian Penugasan Pelaksanaan Pengabdian kepada Masyarakat Program Mono Tahun Dosen Muda Tahun Anggaran 2019. Oleh karena itu, diucapkan terima kasih kepada Rektor Universitas Sumatera Utara atas dukungan dana dan fasilitas yang diberikan. Terima kasih juga kepada Mitra pada kegiatan pengabdian ini.

\section{DAFTAR PUSTAKA}

Agustina, W. 2009. Desain Kemasan dan Label Produk Makanan. Kumpulan Modul Pelatihan. UPT B2PTTG-LIPI Subang.

Ardiyanto, Bagus. 2013.“Analisis Bantuan Kredit Dari Program Kemitraan Dan Bina Lingkungan (Pkbl)Pt. Pelabuhan Indonesia III (Persero) Cabang Tanjung Emas Semarang Terhadap Perkembangan Usaha Mikro KecilDi Kota Semarang”. Semarang hal. 1-59 :Universitas Diponegoro.

Cenadi, Christine Suharto. 2000. Peranan Desain Kemasan dalam Dunia Pemasaran Jurnal Nirmana Vol 2. No. 1, Januari 2000.

Damayanti, C. (2015). Packaging The Brand. Modul pelatihan. Rumah Kemasan Bandung

Firzan, M. (2015). Modul Pelatihan Branding Untuk Usaha Kecil Menengah. Modul. Rumah kemasan

Mulyadi Nitisusastro. 2015. Kewirausahaan dan Manajemen Usaha Kecil, Penerbit, Alfabeta.

Suryana. 2006. "Kewirausahaan-Pedoman Praktis :Kiatdan Proses Menuju Sukses". Bandung :Salemba Empat

Tri,Rizki, dkk. 2013. "Pemberdayaan Usaha Mikro, Kecil Dan Menengah(Umkm) Melalui Pembiayaan Dengan Prinsip Bagi Hasil Oleh Lembaga Keuangan Syariah”.Malang hal. 1-24: Universitas Brawijaya Malang.

Triyono, A. 2002. Modul Pengemasan Produk Makanan, Kumpulan Modul PelatihanUPT B2PTTG-LIPI Subang 